UDC 615.224

DOI: $10.15587 / 2519-4852.2017 .113534$

\title{
DETERMINATION OF THE NEED FOR MEDICINAL PRODUCTS OF PLANT ORIGIN USED FOR TREATING CARDIOVASCULAR DISEASES
}

\author{
(C) I. Sakhanda, K. Kosyachenko, T. Nehoda
}

\begin{abstract}
Мета роботи - визначити потребу у лікарських препаратах рослинного походження для лікування сериево-судинних захворювань.

Матеріали та методи. Прогнозування потреби в кардіологічних лікарських засобах в цілому, $і$ в лікарських препаратах рослинного походження (ЛП РП) зокрема, зростає у міру збільшення чисельності населення, тривалості життя, під впливом сочіально-демографічних чинників, а головне - зі збільшенням числа літніх людей.
\end{abstract}

Результати. На фармацевтичному ринку України серед лікарських засобів рослинного походження домінують лікарські препарати вітчизняного виробництва, щзо значно знижує вартість терапії $і$ робить багато лікарських препаратів доступними для сочіально незахищених верств населення.

Висновки. Зважаючи на особливості сучасних сочіально-економічних умов, недостатність фінансової лікарської допомоги за рахунок державного бюджету і необхідність рішення проблем вдосконалення організації лікарської допомоги хворим з сериево-судинною патологією, нами проведено прогнозування перспективного попиту на лікарські препарати рослинного походження. Важливий етап при виборі методів прогнозування - цее можливість залучення необхідного числа показників, щзо є характеристикою нормативного методу, доступність і простота якого дозволяють використати його фахівиями, щуо не мають спеціальної математичної підготовки на рівні медичних і фармацевтичних організачій.

Профілактика захворювань повинна грунтуватися на здійсненні державних програм профілактики $і$ укріплення здоров'я. Це дозволить удосконалювати і активно використати методи раннього виявлення сочіальних і економічних чинників, щзо є загрозою розвитку захворювань серцево-судинної системи

Ключові слова: лікарські препарати рослинного походження, серцево-судинні захворювання, маркетингові дослідження, потреба

\section{Introduction}

At the stages of marketing research, the study of the assortment, the solvency of consumers should be conducted with the obligatory consideration of regional peculiarities, the real financial possibilities of the medical and preventive institution and the solvency of the population, as well as factors influencing the choice of the medicinal product by medical, pharmaceutical workers and the population [1].

In the pharmaceutical market of Ukraine, MP PO dominated by drugs domestically, which significantly reduces the cost of therapy and makes many drugs affordable for the socially unprotected strata of the population [2].

2. Formulation of the problem in a general way, the relevance of the theme and its connection with important scientific and practical issues

Forecasting the need for cardiac medicines in general, and in medicinal products of plant origin (MP $\mathrm{PO}$ ), in particular, is increasing as the population, life expectancy, under the influence of socio-demographic factors, and, most importantly, with the increase in the number of elderly people. When solving problems facing health care in the field of drug provision of the population, a regular analysis of the pharmaceutical market and a forecast of the need for medicines in the context of the pharmacotherapeutic group that is being studied are necessary.
3. Analysis of recent studies and publications in which a solution of the problem and which draws

The recent research and publications that address the issue are coveredin such works on the authors Sakhanda I. V., Siatynia M. L., Nehoda T. S., Volokh D. S., Kosyachenko K. L. and others.

4. Allocation of unsolved parts of the general problem, which is dedicated to the article

The problem of reliability of providing consumers of medicinal products of plant origin directly depends on the creation of an optimal stock of these medicines. WHO recommends the following approach: «The goal is to ensure that the size of the supply meets the demand, while the stock of medicines should be minimal, but to ensure that they are available in the event of an unexpected delay in delivery».

\section{Formulation of goals (tasks) of Article}

On the pharmaceutical market of Ukraine, among medicinal products of plant origin, domestically produced drugs, which significantly reduces the cost of therapy and makes many medicines available to socially unprotected populations. A characteristic feature of the problem of determining the need for highly effective medicinal products of plant origin is the presence of unpredictable factors affecting the complex system of formation and satisfaction of demand (the emergence of new medicines, different levels of doctors' awareness, 
educational work among the population, etc.) [3].Taking into account the peculiarities of the current social and economic situation, the inadequacy of financial drug assistance at the expense of the state budget and the need to address the problems of improving the organization of medicinal care for patients with cardiovascular pathology, we have forecasted the long-term demand for medicinal products of plant origin.

\section{Statement of the basic material of the study (methods and objects) with the justification of the results}

An important stage in the choice of forecasting methods is the possibility of attracting the required number of indicators, which is a characteristic of the normative method, whose accessibility and simplicity make it possible to use it by specialists who do not have special mathematical training at the level of medical and pharmaceutical organizations.

The basis of this method is calculated norms of consumption of drugs, which reflect the characteristic properties and regularities of the normalized object. Calculation of the rate of consumption of drugs is based on the study of morbidity by nosological forms and the optimal set of drugs for the course of treatment, as well as the quantitative consumption of these drugs while being prescribed to the patient.

The advantage of this method is the ability to take into account changes in factors that affect the need. The most difficult problem of using the normative method is the considerable laboriousness of the development of norms, which requires the processing and analysis of large amounts of information [4].

An algorithm for predicting the need for medicinal products of plant origin is shown in Fig. 1.

The application of the normative method requires the calculation of the following indicators:

- forecast of the number of medicinal products of plant origin users;

- consumption intensity factors for each drug;

- consumption of each medicinal product for one year of use by one consumer.

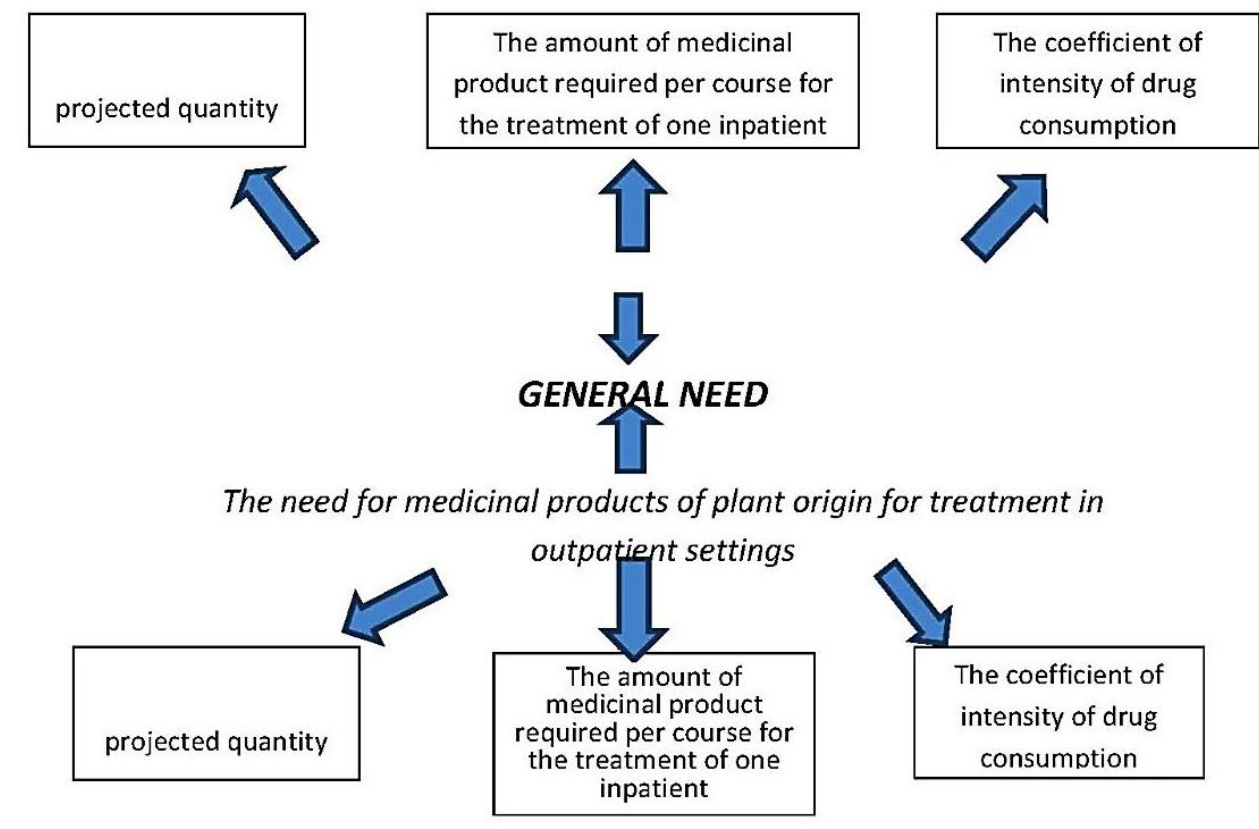

Fig. 1.An algorithm for predicting the need for medicinal products of plant origin

Calculation of the need for drugs for the treatment of i-th nosology in the hospital in physical terms (in packages) for both outpatient and inpatient patients was carried out according to the formula (formula 1) [2]:

$$
N i j=\text { Xijfact } \cdot I i j \cdot E i,
$$

where $\mathrm{Nij}$ - the need for the $\mathrm{j}$-th drug in the $\mathrm{i}$-th nosology;

$\mathrm{i}$ - disease nosology;

$\mathrm{j}$ - specific drug;

$\mathrm{Xij}$ - an approximate norm of the need of $\mathrm{j}$-drug for the course of treatment of one patient;

Iij - intensity factor of the $\mathrm{j}$-drug requirement;

$\mathrm{Ei}$ - expected number of patients in the i-clinical group.
According to the proposed methodology, we determined the long-term need in 2011-2017 years in medicinal products of plant origin. The consumption of this group of drugs is predictable, since most drugs are prescription drugs. This fact makes it possible to accurately take into account the number of consumers in polyclinics and hospital departments [5]. The need is calculated separately for each drug name in both quantitative and summary terms. In sum, the need for a drug for a course of treatment for one patient was determined by the formula (2) [2]:

$$
S=N i j \cdot C,
$$

where $\mathrm{Nij}$ - the need for medicinal product in quantitative terms; 
$\mathrm{C}$ - the cost of medicinal product.

According to the scheme for determining the need for medicinal products of plant origin, it is necessary to know:

- the optimal assortment of medicinal products of plant origin;

- the amount of medicinal products of plant origin for one patient; product;

- the intensity of consumption of the medicinal

- the planned number of patients.

At the first stage, the intensity of consumption of drugs was calculated.

The intensity factor of consumption shows how often each specific medication is prescribed, in how many percentages of cases it is used, which part of consumers in total use this medication, and is calculated by the formula (3) [2]:

$$
I i j=\frac{n i}{N}
$$

where Iij - intensity factor of medicinal products of plant origin consumption;

$\mathrm{n}-$ the number of consumers who use the drug in this sample;

$\mathrm{N}$ - the total number of consumers in the sample $(\mathrm{N}=420$ people).

The results of the calculation of the intensity factors are given in Table 1.

Table 1

Analysis of the frequency of medicinal products of plant origin for the treatment of cardiovascular disease (2006-2016)

\begin{tabular}{|c|c|c|c|c|c|}
\hline $\begin{array}{c}\text { Name of medicinal products } \\
\text { of plant origin }\end{array}$ & $\begin{array}{c}\text { The average price of } \\
\text { the package }(\mathrm{S}), \\
\text { UAH }\end{array}$ & $\begin{array}{l}\text { The number of } \\
\text { appointments }\end{array}$ & $\begin{array}{l}\text { Number of packages } \\
\text { for the course of } \\
\text { treatment }(X)\end{array}$ & $\mathrm{n}$ & Iij \\
\hline $\begin{array}{l}\text { Digoxin tablets } \\
0,25 \mathrm{mg} \text { No. } 30\end{array}$ & $8-40$ & 323 & ( & 156 & 0.37 \\
\hline $\begin{array}{l}\text { Digoxin, solution for injection } \\
0,25 \%-1 \mathrm{ml} \text { No. } 10\end{array}$ & $28-20$ & 20 & 1 & 71 & 0.17 \\
\hline $\begin{array}{l}\text { Corglycon, solution for injec- } \\
\text { tion } \\
0,06 \%-1 \mathrm{ml} \text { No. } 10\end{array}$ & $21-20$ & 335 & 1 & 53 & 0.13 \\
\hline $\begin{array}{l}\text { Platyphyllini hydrotartras } \\
0,2 \%-1 \mathrm{ml} \text { No. } 10\end{array}$ & $28-50$ & 500 & 1 & 40 & 0.48 \\
\hline $\begin{array}{l}\text { Papaverine hydrochloride } \\
2 \%-2 \mathrm{ml} \text { No. } 10\end{array}$ & $20-20$ & 1303 & 1 & 200 & 0.22 \\
\hline Strophantine D & $22-20$ & 200 & 1 & 32 & 0.08 \\
\hline Strophantine & $21-20$ & 10 & 1 & 15 & 0.04 \\
\hline Allapinin & $356-00$ & 144 & 1 & 64 & 0.15 \\
\hline
\end{tabular}

Then based on the analysis of the patient's case histories, drug intake standards were determined (Xij fact).

Recommendations for the obtained values Xij fact as indicative of standards initially held their statistical processing on the coefficient of variation, which confirmed that the value of the average actual flow has little variation [6].

So the obtained values of Xij fact can be used as an approximate standard and used to determine the need for medicines in the treatment of cardiovascular diseases. The expected number of patients was determined by the method of average geometric parameters according to statistical data for the period 2011-2016 (formula 4, 5) [2]:

$$
\begin{aligned}
& T=\frac{B 3}{B 2}, \\
& T c p=n \sqrt{T 1 \cdot T 2 \cdot T 3 \cdot T 4 \cdot T 5},
\end{aligned}
$$

where B1, B2...B5 - the number of patients with cardiovascular diseases for the first, second ... the 5th considered years in this hospital; Tcp (middle) - average growth rate; $\mathrm{T}-$ the rate of increase in the incidence rate by years.
The expected (planned) number of patients is determined by the formula 6 [2]:

$$
B i=B 3 \cdot \text { Tmiddle, }
$$

where $\mathrm{Bi}$ - expected number of cardiac patients; $\mathrm{B} 3$ number of patients in the pre-planning period; Tmid average growth rate.

According to statistical data, the number of patients treated in the planned hospitals for the period 2006-2016 was:

- 2011year - 2630 people;

- 2012 year -2560 people;

- 2013 year - 2631 people;

- 2014 year -2664 people;

- 2015 year -2690 people;

-2016 year -2720 people.

From 2011 to 2016, the number of patients treated was steadily increasing.

The increase in morbidity, which occurs, we associate with the increase in the proportion of older age groups in the total population of the country. We calculated the expected number of patients with this pathology for city hospitals. 
Next the calculation of the need for each medicinal products of plant origin over the period 2015-2017 was carried out.
The calculation took into account the period of treatment of 1 patient - 21 days. The results of the calculation are shown in Table 2.

Table 2

Calculation of hospital needs in medicinal products of plant origin which used to treat patients with cardiovascular pathology

\begin{tabular}{|l|c|c|c|c|c|c|}
\hline \multirow{2}{*}{$\begin{array}{l}\text { Name of medicinal } \\
\text { products of plant origin }\end{array}$} & \multicolumn{2}{|c|}{2015} & \multicolumn{2}{|c|}{ Forecast needs for years } \\
\cline { 2 - 6 } & $\begin{array}{c}\text { absolute } \\
\text { unit }\end{array}$ & sum, UAH & absolute unit & sum, UAH & absolute unit & sum, UAH \\
\hline $\begin{array}{l}\text { Digoxin tablets } \\
0,25 \text { mg No. 30 }\end{array}$ & 333 & $2797-20$ & 343 & $2881-20$ & 353 & $2965-20$ \\
\hline $\begin{array}{l}\text { Digoxin, solution } \\
\text { for injection } \\
0,25 \%-1 \text { ml No. 10 }\end{array}$ & 21 & $592-20$ & 22 & $620-40$ & 23 & $648-60$ \\
\hline $\begin{array}{l}\text { Corglycon, solution for } \\
\text { injection } \\
0,06 \%-1 \text { ml No. 10 }\end{array}$ & 345 & $7314-00$ & 355 & $7526-00$ & 366 & $7759-20$ \\
\hline $\begin{array}{l}\text { Platyphyllini } \\
\text { hydrotartras } \\
0,2 \%-1 m l \text { No. 10 }\end{array}$ & 515 & $14677-50$ & 530 & $15105-00$ & 546 & $15561-00$ \\
\hline $\begin{array}{l}\text { Papaverine } \\
\text { hydrochloride } \\
2 \%-2 \text { ml No. 10 }\end{array}$ & 1342 & $26840-00$ & 1382 & $27640-00$ & 1423 & $28460-00$ \\
\hline Strophantine D & 2060 & $45732-00$ & 2122 & $47108-40$ & 2186 & $48529-20$ \\
\hline Strophantine & 21 & $233-20$ & 12 & $254-40$ & 13 & $275-60$ \\
\hline Allapinin & 149 & $54385-00$ & 154 & $56210-00$ & 159 & $58035-00$ \\
\hline Together & $152570-90$ & & $157345-40$ & & $162233-80$ \\
\hline
\end{tabular}

Economic evaluation, together with studies of clinical effectiveness, allows a more rational allocation of available resources. Unfortunately, it should be noted that the low demand for pharmacoeconomic analysis results does not yet allow the full redistribution of the financial flow of budget funds to the full extent [7-10]. In this regard, special attention should be paid to the profitability of the drug from the "cost-minimization" position, which should be evaluated in a comprehensive manner, taking into account the cost of inpatient and outpatient care.

\section{Conclusions}

The system of measures to improve the organization and improve the quality of therapeutic care for the population should include organizational and methodological issues of providing and managing the quality of medical care and drug provision.

The most important place in reforming the industry should be allocated to improving the outpatient and polyclinic service are increasing the efficiency of using material and human resources, introducing new progressive forms of work into practice.

The solution of these problems is determined by the wide introduction of fairly simple and massive measures to improve the living environment, the implementation of preventive measures to prevent the realization of the risk of developing cardiovascular diseases, giving the maximum results at minimum costs.

\section{Findings from the research and prospects of further development of this area}

In the present conditions, it is important to standardize the structure, types and volumes of treatment and rehabilitation activities, technologies and results, and the functioning of the system of medical and social care institutions for patients.

Prevention of diseases should be based on the implementation of government programs for prevention and promotion of health. This will improve and actively use methods of early detection of social and economic factors, which is a threat of development of diseases of the cardiovascular system.

Based on the studies, methodical recommendations have been developed that contribute to improving the quality of treatment for patients suffering from cardiovascular diseases.

Declaration on the absence of a conflict of interest. There are no conflicts of interest in this article.

\section{References}

1. Avksenteva, M. V. Ekonomicheskaya otsenka effektivnosti lekarstvennoy terapii (farmakoekonomicheskiy analiz) [Text] / M. V. Avksenteva, P. A. Vorobev, V. B. Gerasimov. - Moscow: Nyudiamed, 2015. - 80 p.

2. Telitsyin, V. P. Assortiment i assortimentnaya politika aptechnogo uchrezhdeniya [Text]: sb. nauch. tr. / V. I. Telitsyin // Razrabotka, issledovanie i marketing novoy farmatsevticheskoy produktsii. - 2015. - Vol. 60. - P. 596-598.

3. Apazov, A. D. Zakonodatelnyie i ekonomicheskie ocnovyi formirovaniya tsivilizovannogo farmatsevticheskogo ryinka [Tekst] / A. D. Apazov // Novaya apteka. - 2011. - P. 9-12. 
4. Zaliska, O. M. Vikoristannya metodiv farmako-ekonomichnoyi otsinki likarskih zasobiv v Ukrayini [Text]: metod. rek. / O. M. Zaliska. - Lviv, 2012. - 23 p.

5. Nehoda, T. Measures marketing plan activities for branch offices of pharmacies (for phyto pharmacy departments) [Text]: III Intern. Scient. and Pr. Conf. / T. S. Nehoda, I. V. Sahanda // Topical researches of the World Science. - Dudai, 2017.

6. Gromovik, B. P. Harakteristika osnovnih metodik viznachennya konkurentospromozhnosti likarskih zasobiv [Text]/ B. P. Gromovik // Farmatsevtichniy zhurnal. -2012. - P. 7-11.

7. Sakhanda, I. V. Metodychni pidkhody do vyznachennia potreby v likarskykh zasobakh roslynnoho pokhodzhennia, shcho zastosovuiutsia dlia likuvannia sertsevo-sudynnykh zakhvoriuvan [Text]: Mizhnar. nauk.-pr. konf. / I. V. Sakhanda, T. S. Nehoda, M. L. Siatynia // Aktualni pytannia suchasnoi medytsyny. - Lviv, 2015. - P. 42-45.

8. Zaliska, O. M. Farmakoekonomika: teoriya i praktika [Tekst] / O. M. Zaliska // Farmatsevtichniy zhurnal. - 2010. P. $10-16$.

9. Sakhanda, I. V. Marketynhovi doslidzhennia suchasnoho stanu rynku likarskykh zasobiv roslynnoho pokhodzhennia [Text] / I. V. Sakhanda // Zbirnyk naukovykh prats spivrobitnykiv NMAPO imeni P. L. Shupyka. - 2016. - Vol. 26. - P. $250-254$.

10. Avksenteva, E. M. Nauchnoe obosnovanie ratsionalnoy farmakoterapii [Text] / E. M. Avksenteva, P. A. Vorobev // Remedium. - 2013. - Vol. 12. - P. 11-12.

Дата надходження рукопису 18.08.2017

Sakhanda Ivanna, Assistant, Department of Pharmacy and Industrial Technology of Drugs, Bogomolets National Medical University, T. Shevchenko blvd., 13, Kyiv, Ukraine, 01601

E-mail: sahanda.ivanna@ukr.net

Kosyachenko Kostyantyn, Doctor of Pharmaceutical Sciences, Head of the Department, Department of Pharmacy and Industrial Technology of Drugs, Bogomolets National Medical University, T. Shevchenko blvd., 13, Kyiv, Ukraine, 01601

E-mail: provisor@i.ua

Nehoda Tatyana, PhD, Associate Professor, Department of Pharmacy and Industrial Technology of Drugs, Bogomolets National Medical University, T. Shevchenko blvd., 13, Kyiv, Ukraine, 01601

E-mail: t-negoda@meta.ua 